\title{
Texture analysis of blanched vegetables using high- and low-speed measuring methods
}

\author{
Christian Schmitr $^{\mathrm{a}, \mathrm{b}^{*}}$, Thomas Friedi ${ }^{\mathrm{a}, \mathrm{b}}$, Nadine Mattes $^{\mathrm{b}}$, Uwe Grupa ${ }^{\mathrm{b}}$, And \\ Oliver Hensel ${ }^{\mathrm{a}}$ \\ a Faculty of Organic Agricultural Sciences, Section of Agricultural Engineering, University of Kassel, \\ Nordbahnhofstraße 1 a, 37213, Witzenhausen, Germany \\ b Department of Food Technology, University of Applied Sciences Fulda, Leipziger Straße 123, 36037 Fulda, \\ Germany \\ ${ }^{*}$ Corresponding author \\ christian.schmitt@lt.hs-fulda.de \\ TEL: +49 (0) 66196402896 \\ FAx: +49 (0) 6619640529
}

Received: 15 April 2016; Published online: 18 April 2017

\begin{abstract}
Quality reductions of raw and cooked vegetables are caused by forces generated during industrial high-speed manufacturing. However, the transferability of low-speed texture measurement methods to high speed processes is limited. Therefore, analyses with a low-speed uniaxial compression test (breaking strength $\sigma$, breaking strain $\varepsilon$ ) and a high-speed pendulum test (relative fracture height $\Delta h)$ at different speeds $\left(3.6,4.4,5.3 \mathrm{~m} \mathrm{~s}^{-1}\right)$ were carried out. Textural values for potatoes, carrots and celeriacs ( 0 to 25 min cooking time) were recorded to compare the two measurement methods. Furthermore, whether the increase of textural values of blanched vegetables measured with low-speed methods, was also observable with high-speed methods, was also investigated. Low to medium rank correlation coefficients $\left(r_{S}<0.659\right)$ between parameters of the two methods were calculated. In contrast to $\sigma$ and $\varepsilon, \Delta$ h-values indicate a distinct initial increase as well as textural maxima between 5.0 to 12.5 min cooking time for all tested potato and carrot varieties. On the other hand, most celeriac samples did not exhibit an increase in texture with respect to cooking time. Therefore, a textural analysis at high speeds is necessary for the prediction of textural characteristics of blanched vegetables during high-speed processing in order to reduce quality degradation.
\end{abstract}

Keywords: Texture of vegetables; Fracture; Uniaxial compression test; Pendulum test; Cooking time

\section{Introduction}

Vegetables are treated with high-speed processes during manufacturing. Typical processes include transportation, such as pumping through pipes or filling processes. High-speed processes lead to mechanical stresses that result in quality losses such as bruises or fracture (Mohsenin, 1986). The most obvious quality loss is fracture. These quality losses primarily depend on the physico- mechanical and biological characteristics of the vegetables (Bentini, Caprara, \& Martelli, 2006). These factors determine the texture of vegetables (Peleg, 2006).

The texture of vegetables depends on several factors including the variety of vegetable, time of harvest, as well as cultivation and storage conditions (Bourne, 2002a). Additionally, texture is influenced by the time of cooking; several chemical and physical modifications play an important 


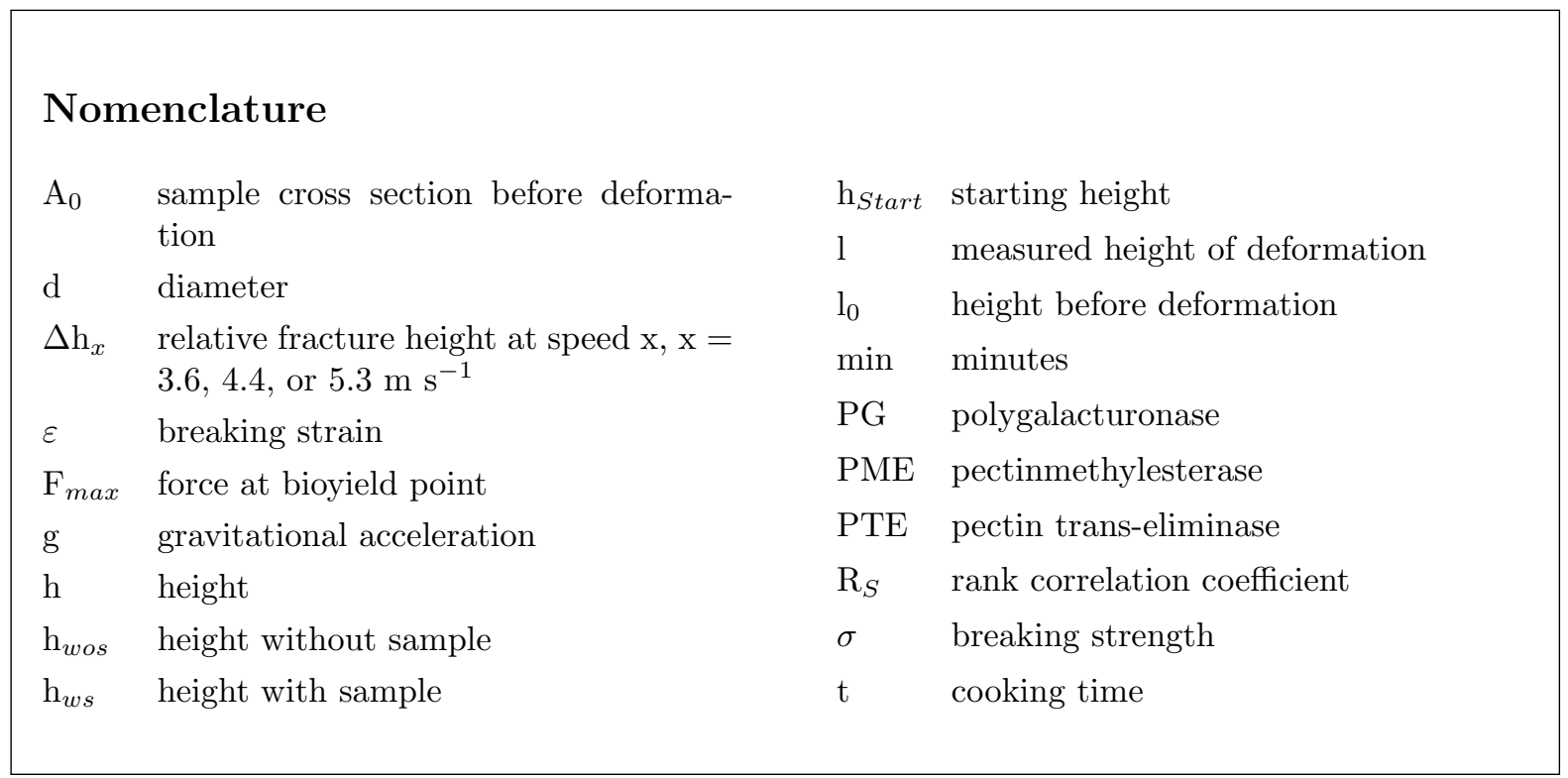

role (Ternes, 2008). Initially, $\mathrm{Ca}^{2+}$ diffuses out of the middle lamellae, and there is an expansion of intercellular space during cooking. Furthermore, starch swells and gelatinizes between 55 and 90 ${ }^{\circ} \mathrm{C}$ particularly for potatoes. The denaturation of proteins in cell components and the destruction of cell organelles change the texture of cooked vegetables as well as the diffusion of salts and liquid. At longer cooking times, water moves into the cells and depolymerisation of pectins in the middle lamellae and the cell walls occurs. Depolymerisation is based on heat-induced $\beta$ - hydrolytic elimination and enzymatic degradation (Waldron, 2004). An increase in the firmness of potatoes during thermal treatment (20 to 40 min) at $60{ }^{\circ} \mathrm{C}$ was detected by Alvarez, Canet, and Tortosa (2001). An increase in the firmness of blanched vegetables has often been observed with low-speed measurement methods. For example, in the study of Alvarez et al. (2001) increasing values for the modulus of rigidity (shear test with a shear cell; $0.4 \mathrm{~m} \mathrm{~min}^{-1}$ ) and the relaxation gradient (compression by parallel plates; $0.4 \mathrm{~m} \mathrm{~min}^{-1}$; 1 min relaxation time) are measured. This can be explained by theories based on the chemical and physical modifications mentioned above (Alvarez et al., 2001).

Most studies of textural properties use methods with lower speeds. However, the textural values of vegetables are affected by the measurement speed (Mohsenin, 1986). Hence, transfer of information on the textural characteristics of vegetables processed at high speeds is difficult based on results from low-speed measurement methods. The resistance against fracture at low speeds can be determined with a uniaxial compression test. Impact tests can be used to measure the texture at higher speeds (Agulheiro Santos \& Roseiro, 2012). Insufficient data are available on the influence of cooking time on the possible decrease and increase in the textural values of vegetables measured at higher speeds. Therefore, optimization of high-speed processes for cooked vegetables based on relevant textural data is not possible.

The objective of this survey was to evaluate the differences in high- and low-speed measurement methods regarding the textural values of vegetables with various cooking times. Additionally, the increase of firmness of blanched vegetables was analyzed with high-speed measuring methods. 
Texture analysis of blanched vegetables $\mid 3$

\section{Materials and Methods}

\subsection{Samples}

The vegetable samples consisted of potatoes, carrots and celeriacs bought from local stores. Different varieties of waxy ("Allians", "Ditta", "Princess Amandine") and floury potatoes ("Melody", "Gunda", "Alpha") were analyzed. Three samples of carrots were tested: "fresh", "ecological cultivation" and "Frucht Hartmann". Additionally, celeriacs tested in this study were purchased from the "Kaufland", "Groma" and "Frucht Hartmann" grocery stores.

\section{$2.2 \quad$ Preparation of samples}

All vegetables were cut into cuboids of approximately $3.0 \times 3.0 \times 4.0 \pm 0.5 \mathrm{~cm} .1 .0 \pm 0.2 \mathrm{~kg}$ of samples were cooked in $3.0 \pm 0.1 \mathrm{l}$ boiling water for a defined cooking time $(\mathrm{t})$. Sample cuboids were strained and covered with $3.0 \pm 0.1 \mathrm{l}$ of tap water $\left(20.0 \pm 2.0^{\circ} \mathrm{C}\right)$ for a $30 \mathrm{~min}$ cooldown. Finally, the cuboids were strained again, and the samples were cut with a cork borer and knife to their final size.

\subsection{Textural analysis}

The texture of the vegetables was evaluated with two different methods. A uniaxial compression test was used for low speeds because shear stresses, one of the main mechanical stresses on vegetables during processing, can be directly measured (Hamann, Zhang, Daubert, Foegeding, \& Diehl, 2006). Furthermore, an impact test was used to test the vegetables at high speeds. Forces due to the impact test are comparable to the mechanical stresses on vegetables during processing (Bourne, 2002c).

\section{Uniaxial compression test}

Samples were investigated with a Texture Analyzer (TA.XT2, Stable Micro Systems LTD) at $22.0 \pm 2.0{ }^{\circ} \mathrm{C}$. The samples had a height $(\mathrm{h})$ of $15.0 \mathrm{~mm}$ and a diameter $(\mathrm{d})$ of $11.5 \pm 0.5$ $\mathrm{mm}$. A cylindrical plate of $100 \mathrm{~mm}$ was used for compression of the samples to a height of
$6.0 \mathrm{~mm}$ at a cross-head speed of $3.0 \mathrm{~mm} \mathrm{~s}^{-1}$. With exponent 6.1.5.0 (Stable Micro Systems LTD), the bioyield point is identified in the forcehigh-diagram (Khan \& Vincent, 1993). Breaking strength $\sigma$ and breaking strain $\varepsilon$ at the bioyield point were calculated according to Hamann et al. (2006), with force $\mathrm{F}_{\max }$ at bioyield point, sample cross section before deformation $\mathrm{A}_{0}$, height before deformation $l_{0}$ and measured height of deformation $\mathrm{l}$ :

$$
\begin{gathered}
\sigma=\frac{F_{\max } \times(1-\varepsilon)}{A_{0}} \\
\varepsilon=\ln \left(2-\frac{\left(l_{0}-l\right)}{l_{0}}\right)
\end{gathered}
$$

The Hencky strain and a Poisson's ration of 0.5 for ideal materials were used in this test (Bourne, $2002 \mathrm{~b})$. A breaking angle of $45^{\circ}$ results from shear stresses (Hamann et al., 2006). Therefore, only upright samples with a breaking angle of $45^{\circ}$ after deformation were considered for calculation. Uniaxial compression tests were carried out in six-fold replicates, and mean values and standard deviations were calculated. Additionally, the measured values were tested for normal distribution (Shapiro-Wilk test) and homogeneity of variance (F-test). Significant differences were determined by using the software R. 3.1.0. for $\sigma$ and $\varepsilon$ (two-sided, $\alpha=0.05$ ) using the t-test, Welch's t-test and Mann-Whitney U test.

\section{Impact test}

The setup of the pendulum test (Figure 1) was adapted from Dutt and Datta (1999), with different setup dimensions and determination of the reversal point of the pendulum. The pendulum arm (stainless steel, $1.0 \mathrm{~cm}$ diameter) together with the stainless steel threshing plate $(10 \mathrm{~cm}$ length, $10 \mathrm{~cm}$ width, $1 \mathrm{~cm}$ depth) had a length of $1.85 \mathrm{~m}$ and was fixed at a wooden holder via a stainless steel bearing ( 4 inch door hinge). These devices are fitted together by stainless steel screws of various sizes. A steel bench vise (drill press vise clamp bench) clamped five cylindrical samples $(\mathrm{h}=25.0 \mathrm{~mm} \pm 1.5 \mathrm{~mm}, \mathrm{~d}=17.5$ $\mathrm{mm} \pm 0.5 \mathrm{~mm}$ ) that overlapped $15.0 \mathrm{~mm}$. The distance between the threshing plate and the top of bench vice was $1.0 \mathrm{~mm}$. The pendulum initiates its swing at a starting height $\left(h_{\text {Start }}\right)$ and

IJFS | April 2017 | Volume 6 | pages 1-12 
shears the cylindrical samples in two pieces due to the movement of the pendulum. The upper part is flying away and the lower is staying in the bench vice. The reversal point was determined optically with a high-speed camera (Casio Exilim EX-FH25). The movement was recorded with 240 frames per second. At the reversal point, the swinging height of the pendulum can be read of a scale on paper in the background of the pendulum. The swinging height is proportional to the fracture energy defined by Dutt and Datta (1999). The texture parameter "relative fracture height $\Delta h "$ is the difference between the measured height without $\left(h_{w o s}\right)$ and with samples $\left(h_{w s}\right)$ and is directly proportional to the fracture energy defined by Dutt and Datta (1999). Three different impact speeds were tested in this study. These were generated by three different starting heights $\left(h_{\text {start }}\right)$. The corresponding speeds can be calculated with a gravity acceleration of $\mathrm{g}=9.81 \mathrm{~m} \mathrm{~s}^{-2}$ and starting heights of $0.65,1.00$ and $1.45 \mathrm{~m}$ (Agulheiro Santos \& Roseiro, 2012). These heights result in impact velocities of 3.6, 4.4 and $5.3 \mathrm{~m} \mathrm{~s}^{-1}$. The three different speeds refer to the relative fracture height parameters $\Delta h_{3.6}, \Delta h_{4.4}$ and $\Delta h_{5.3}$. The pendulum test was carried out in duplicate. Mean values and standard deviations were calculated.

\subsection{Experimental Design}

Two different test series were carried out in this study.

First, potatoes ("Allians", "Ditta", "Gunda", "Melody"), two varieties of carrots (ecological cultivation and fresh carrots) and celeriacs ("Groma", "Kaufland") were tested to compare the results of the uniaxial compression test with those of the pendulum test. Samples were tested with the uniaxial compression test at cooking times of $0.0,5.0,10.0,15.0,20.0$ and $25.0 \mathrm{~min}$. Additionally, equally thermal treated samples were tested at two speeds ( 3.6 and $5.3 \mathrm{~m} \mathrm{~s}^{-1}$ ) in the pendulum test. A correlation analysis was done for the parameters $\sigma, \varepsilon, \Delta h_{3.6}$ and $\Delta \mathrm{h}_{5.3}$. and the rank correlation coefficient $\left(\mathrm{r}_{S}\right)$ was calculated, due to possible non-linear correlations. Significance of correlation was tested by using the software SPSS Statistics 20 (two-sided t-test, $\alpha$
$=0.01)$.

Secondly, additional trials were carried out to evaluate the influence of blanching on the textural value increase measured at high speeds. Carrot ("Frucht Hartmann") and celeriac ("Frucht Hartmann") as well as "Princess Amandine" and "Alpha" potatoes were tested at 3 different speeds with the pendulum test. Cooking times of $0.0,2.5,5.0,7.5,10.0,12.5$ and $15.0 \mathrm{~min}$ were tested for each sample.

\section{Results and Discussion}

\subsection{Comparison between high- and low-speed texture measuring methods}

The results of high- and low-speed texture measuring methods are shown in Table 1.

At first, the measured values of $\sigma$ and $\varepsilon$ were compared. The mean values of $\sigma$ decreased with increasing cooking time for all vegetables tested. In contrast, the values of $\varepsilon$ for both carrot samples and the waxy potato "Ditta" showed a significant maximum at $5.0 \mathrm{~min}$ cooking time. Additionally, $\varepsilon$ was constant for the remaining potatoes and celeriacs up to cooking times of 5.0 and $10.0 \mathrm{~min}$, respectively. Therefore, $\varepsilon$ decreased with higher cooking times. A $r_{S}$ of 0.748 implies a positive, high and significant correlation between $\varepsilon$ and $\sigma$ (Bühl, 2010). Hence, the measured values of $\varepsilon$ and $\sigma$ were related, but the results of one parameter cannot be transferred to the other. Therefore, both parameters represent different textural characteristics and have to be evaluated separately for the vegetables tested.

Next, $\Delta h_{3.6}$ and $\Delta h_{5.3}$ were compared. Carrots showed a maximum for both parameters at 10.0 min cooking time whereas potatoes had maxima between 5.0 to $10.0 \mathrm{~min}$. Thereafter, the $\Delta h_{3.6}$ and $\Delta h_{5.3}$ values decreased with cooking time. No maxima of $\Delta h_{3.6}$ and $\Delta h_{5.3}$ were recognizable for either celeriacs tested. Additionally, both parameters showed a decrease with an increasing cooking time, whereas the values of $\Delta h_{5.3}$ were nearly constant until $\mathrm{t}=10.0 \mathrm{~min}$. A significant correlation between $\Delta \mathrm{h}_{3.6}$ and $\Delta h_{5.3}$ was found with $\mathrm{r}_{S}=0.867$. Therefore, the textural parameters $\Delta h_{3.6}$ and $\Delta h_{5.3}$ correlated highly positively, 


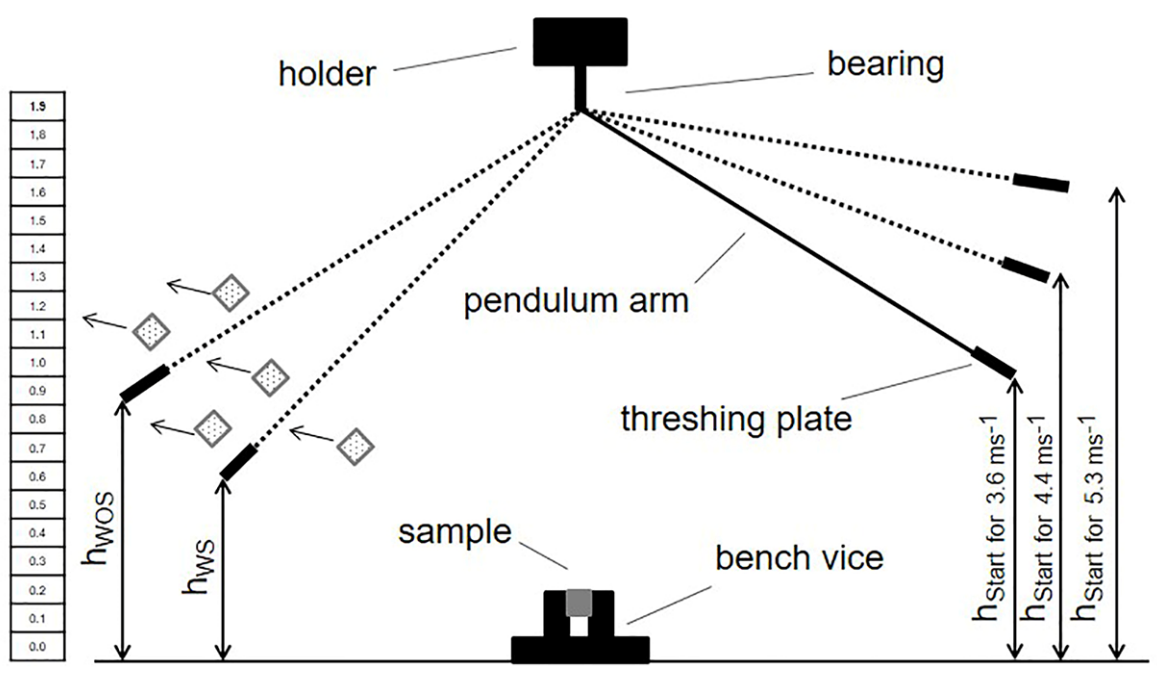

Figure 1: Experimental setup: pendulum test

and the results of one parameter can be transferred to the other (Bühl, 2010). The parameters can be calculated with equation 3 :

$$
\Delta h_{3.6}=1.35 \times \Delta h_{5.3}^{1.123}
$$

The one-way ANOVA shows a significant regression $(\alpha=0.05)$ with $R^{2}=0.784$ and normally distributed residuals. Thus, both parameters measure the same textural characteristics.

Finally, the parameters of the pendulum test were compared with the parameters in the uniaxial compression test. Values of $\varepsilon$ showed partly similar tendencies compared to the values of $\Delta h_{3.6}$ and $\Delta h_{5.3}$. Carrots and the "Ditta" potato had the aforementioned textural maxima of $\varepsilon$, $\Delta \mathrm{h}_{3.6}$ and $\Delta h_{5.3}$ as well as decreasing values with increasing cooking time. Celeriacs had comparable textural values for $\varepsilon$ and $\Delta h_{5.3} . \Delta h_{3.6}$ and $\Delta h_{5.3}$ showed textural maxima for all potatoes tested whereas $\varepsilon$ had a maximum only for the "Ditta" potato. Only celeriac samples showed similar tendencies regarding $\sigma$ and $\Delta \mathrm{h}_{3.6}$. Additionally, $\mathrm{r}_{S}$ between $\sigma$ and $\Delta h_{3.6}(0.659)$ or $\Delta h_{5.3}(0.596)$, respectively revealed significant medium correlations. Significant medium to low correlations were calculated between $\varepsilon$ and $\Delta h_{3.6}$ (0.435) or $\Delta h_{5.3}(0.513)$ (Bühl, 2010). Parameters evaluated from the low-speed uniaxial com- pression test were positively related to the calculated parameters of the high-speed pendulum test. However, a transfer of results from $\sigma$ or $\varepsilon$ to $\Delta h_{3.6}$ or $\Delta h_{5.3}$ was limited based on low $r_{S}$ and different tendencies of the measured parameters. Therefore, there was a difference between high- and low-speed measurement methods of the textural values of vegetables with cooking time. Textural parameters measured at high speeds have to be evaluated separately to assess the textural behavior of vegetables in high-speed processes. There are several possible explanations for this result. The pendulum test applies a dynamic strain whereas the uniaxial compression test uses quasi-static strain. Therefore, different textural characteristics are tested (Luyten, Vanvliet, \& Walstra, 1992). High correlation coefficients between a quasi-static test (cantilever) and a dynamic pendulum test were calculated by measuring the rupture strength of seed pods (Liu, Macmillan, Burrow, Kadkol, \& Halloran, 1994). Thereby, the lack of an even higher correlation was explained by the variance in the texture of the seed pods tested and the measurement principles. The fracture process is an important factor regarding the respective measurement principle (Liu et al., 1994). $\sigma$ and $\varepsilon$ are evaluated at the bioyield point that character- 
6|Schmitt et al.

izes the first cracking of vegetable tissue $(\mathrm{Lu} \&$ Abbott, 2004). In contrast, $\Delta h_{3.6}$ and $\Delta h_{5.3}$ include all three stages of fracture: crack initiation, crack propagation and fracture (Bourne, 2002b). Furthermore, the measurement speeds differ by a factor of 1000. Mohsenin (1986) described the dependency of textural values of vegetables on the measurement speed. For example, low speeds lead to a more viscous characteristic in foods (Luyten et al., 1992).

\subsection{Influence of short time heating process on the texture of vegetables}

The "Princess Amandine" and "Alpha" potatoes as well as the "Frucht Hartmann" carrot showed an increase of $\Delta h_{3.6}, \Delta h_{4.4}$ and $\Delta h_{5.3}$ with increasing cooking time up to a maximum (Table 2 ). The texture maxima of the potatoes were between 5.0 to 12.5 min cooking time and 7.5 to 12.5 min for the "Frucht Hartmann" carrot with respect to the pendulum speed. $\Delta h_{3.6}, \Delta h_{4.4}$ and $\Delta h_{5.3}$ decreased thereafter. These results are similar to the measured values of the first measurement series (Table 1 ) for all carrots and potatoes tested. The maximum values were in the same range, between 5.0 and $10.0 \mathrm{~min}$ for potatoes and $10.0 \mathrm{~min}$ for carrots. These findings suggest an increase in the relative fracture height of blanched potatoes and carrots that can be observed with high-speed measurement methods.

The significant increase of relative fracture height is mainly attributed to enzymatic activity during cooking (Alvarez et al., 2001). Three enzymes especially influence the decomposition of pectin in cell walls and the middle lamellae. Polygalacturonase (PG) and pectin trans-eliminase (PTE) split the polygalacturonic acid (Dave \& Vaughn, 1971; Rehman et al., 2016). This leads to a better solubility and release of pectin from the cell wall and middle lamellae. These processes result in a softening of the tissue (Van Marle et al., 1997). In contrast, pectinmethylesterase (PME) demethylates the pectin (Benen, Van Alebeek, \& Voragen, 2003). The resulting free demethylated carboxyl groups of the pectin can form dimers with $\mathrm{Ca}^{2+}$. They interact as an intercellular con- nector that results in solidification of the structure and an increase in texture (Alvarez et al., 2001; Brejnholt, 2009). The activity of the enzymes depends on the temperature. Optimum PME activity is between $50{ }^{\circ} \mathrm{C}$ and $80{ }^{\circ} \mathrm{C}$ (Van Buren, 1973). PG inactivation starts at $58{ }^{\circ} \mathrm{C}$ and activity of PTE is reduced to under $10 \%$ above temperatures of $75{ }^{\circ} \mathrm{C}$ (Dave \& Vaughn, 1971; Fachin, Van Loey, Indrawati, Ludikhuyze, \& Hendrickx, 2002). The measured core temperature of potatoes and carrots was $50{ }^{\circ} \mathrm{C}$ after $5.0 \mathrm{~min}$. At $7.5 \mathrm{~min}$, the samples partly had a core temperature of $75{ }^{\circ} \mathrm{C}$, and after $12.5 \mathrm{~min}$, the potatoes and carrots reached a temperature above $86{ }^{\circ} \mathrm{C}$. In this way, PME demethylates the pectin between 7.5 and $12.5 \mathrm{~min}$, whereas the activity of PTE and PG is strongly reduced. Almost all the measured maxima of $\Delta h_{3.6}, \Delta h_{4.4}$ and $\Delta h_{5.3}$ occurred at these cooking times, connecting the increasing textural values with PME activity. This theory is consistent with the conclusion of (Sila, Smout, Vu, Van Loey, \& Hendrickx, 2005). They connected the temperature for PME activity with the maximum hardness of carrots in low-speed measurements during blanching. Additionally, the demethylation of pectin reduces the susceptibility of pectin against heat induced hydrolytic $\beta$-elimination. The reduced degradation of pectin results in a lower textural decrease during cooking (Alvarez et al., 2001; Van Dijk, Fischer, Beekhuizen, Boeriu, \& Stolle-Smits, 2002). Furthermore, vegetable cell membranes lose their selective permeability during cooking. Hence, PME is activated by diffusion of extracellular cations inside the cells (Alvarez et al., 2001). Generally, turgor pressure is reduced during cooking because the destruction of the cell membrane leads to lower textural values (Kresic, Lelas, \& Simundic, 2004; Sajnin, Gerschenson, \& Rojas, 1999). However, due to swelling and gelatinization of starch at the beginning of the cooking process, a gel is generated inside the cells (Alvarez et al., 2001; Van Dijk, Beekhuizen, et al., 2002). This increases the pressure and temporarily compensates the loss of turgor pressure (Jarvis, 1998). Loss of $\mathrm{Ca}^{2+}$, expansion of intercellular space, denaturation of proteins, destruction of cell organelles, movement of water, heat induced hydrolytic $\beta$ elimination become predominant with increased 
Texture analysis of blanched vegetables $\mid 7$

Table 1: Breaking strength $(\sigma)$, breaking strain $(\varepsilon)$ and relative fracture height $\left(\Delta h_{x}\right)$ of several waxy and floury potatoes, carrots and celeriac $^{1}$

\begin{tabular}{|c|c|c|c|c|c|}
\hline food samples & $\mathrm{t}[\mathrm{min}]$ & $\sigma\left[N / m^{-2}\right]$ & $\varepsilon[-]$ & $\Delta h_{3.6}[\mathrm{~cm}]$ & $\Delta h_{5.3}[\mathrm{~cm}]$ \\
\hline \multirow[t]{6}{*}{ waxy potato, Allians } & 0.0 & $0.92 \pm 0.08^{a}$ & $0.37 \pm 0.01^{a}$ & $29 \pm 1$ & $17 \pm 1$ \\
\hline & 5.0 & $0.78 \pm 0.12^{b}$ & $0.36 \pm 0.02^{a}$ & $44 \pm 6$ & $25 \pm 3$ \\
\hline & 10.0 & $0.53 \pm 0.10^{c}$ & $0.31 \pm 0.02^{b}$ & $58 \pm 11$ & $27 \pm 1$ \\
\hline & 15.0 & $0.16 \pm 0.02^{d}$ & $0.17 \pm 0.03^{c}$ & $36 \pm 2$ & $19 \pm 3$ \\
\hline & 20.0 & $0.05 \pm 0.01^{e}$ & $0.14 \pm 0.03^{c}$ & $34 \pm 8$ & $12 \pm 1$ \\
\hline & 25.0 & $0.05 \pm 0.03^{e}$ & $0.14 \pm 0.02^{c}$ & $20 \pm 1$ & $12 \pm 2$ \\
\hline \multirow[t]{6}{*}{ waxy potato, Ditta } & 0.0 & $0.93 \pm 0.04^{a}$ & $0.36 \pm 0.01^{a}$ & $22 \pm 2$ & $14 \pm 0$ \\
\hline & 5.0 & $0.88 \pm 0.07^{b}$ & $0.38 \pm 0.01^{b}$ & $39 \pm 3$ & $21 \pm 1$ \\
\hline & 10.0 & $0.51 \pm 0.20^{c}$ & $0.34 \pm 0.07^{a, b}$ & $63 \pm 4$ & $31 \pm 3$ \\
\hline & 15.0 & $0.17 \pm 0.05^{d}$ & $0.20 \pm 0.02^{c}$ & $44 \pm 5$ & $18 \pm 3$ \\
\hline & 20.0 & $0.15 \pm 00.5^{d}$ & $0.19 \pm 0.02^{c, d}$ & $25 \pm 7$ & $14 \pm 0$ \\
\hline & 25.0 & $0.04 \pm 0.02^{e}$ & $0.17 \pm 0.02^{d}$ & $19 \pm 5$ & $14 \pm 2$ \\
\hline \multirow[t]{6}{*}{ floury potato, Melody } & 0.0 & $1.11 \pm 0.12^{a}$ & $0.39 \pm 0.03^{a}$ & $25 \pm 4$ & $16 \pm 1$ \\
\hline & 5.0 & $0.76 \pm 0.14^{b}$ & $0.38 \pm 0.02^{a}$ & $52 \pm 0$ & $29 \pm 3$ \\
\hline & 10.0 & $0.42 \pm 0.11^{c}$ & $0.28 \pm 0.04^{b}$ & $71 \pm 6$ & $28 \pm 2$ \\
\hline & 15.0 & $0.12 \pm 0.07^{d}$ & $0.16 \pm 0.04^{c}$ & $37 \pm 9$ & $20 \pm 1$ \\
\hline & 20.0 & $0.05 \pm 0.01^{e}$ & $0.16 \pm 0.02^{c}$ & $16 \pm 1$ & $10 \pm 1$ \\
\hline & $25.0^{*}$ & - & - & - & - \\
\hline \multirow[t]{6}{*}{ floury potato, Gunda } & 0.0 & $0.93 \pm 0.1^{a}$ & $0.36 \pm 0.02^{a}$ & $44 \pm 5$ & $13 \pm 1$ \\
\hline & 5.0 & $0.85 \pm 0.10^{a}$ & $0.36 \pm 0.02^{a}$ & $85 \pm 12$ & $24 \pm 1$ \\
\hline & 10.0 & $0.62 \pm 0.07^{b}$ & $0.31 \pm 0.03^{b}$ & $69 \pm 5$ & $31 \pm 1$ \\
\hline & 15.0 & $0.23 \pm 0.05^{c}$ & $0.18 \pm 0.02^{c}$ & $26 \pm 5$ & $9 \pm 1$ \\
\hline & 20.0 & $0.08 \pm 0.02^{d}$ & $0.14 \pm 0.02^{d}$ & $14 \pm 5$ & $8 \pm 1$ \\
\hline & $25.0^{*}$ & - & - & - & - \\
\hline \multirow[t]{6}{*}{ carrot, fresh } & 0.0 & $1.52 \pm 0.13^{a}$ & $0.31 \pm 0.02^{a}$ & $39 \pm 2$ & $21 \pm 2$ \\
\hline & 5.0 & $1.18 \pm 0.13^{b}$ & $0.36 \pm 0.02^{b}$ & $50 \pm 0$ & $22 \pm 0$ \\
\hline & 10.0 & $0.58 \pm 0.10^{c}$ & $0.29 \pm 0.02^{c}$ & $58 \pm 19$ & $28 \pm 2$ \\
\hline & 15.0 & $0.25 \pm 0.09^{d}$ & $0.24 \pm 0.02^{d}$ & $44 \pm 3$ & $23 \pm 2$ \\
\hline & 20.0 & $0.20 \pm 0.07^{d}$ & $0.22 \pm 0.02^{e}$ & $34 \pm 0$ & $15 \pm 0$ \\
\hline & 25.0 & $0.20 \pm 0.05^{d}$ & $0.22 \pm 0.04^{d, e}$ & $24 \pm 1$ & $16 \pm 1$ \\
\hline \multirow{6}{*}{$\begin{array}{l}\text { carrot, ecological } \\
\text { cultivation }\end{array}$} & 0.0 & $1.43 \pm 0.26^{a}$ & $0.29 \pm 0.02^{a, b}$ & $42 \pm 5$ & $16 \pm 1$ \\
\hline & 5.0 & $1.09 \pm 0.11^{b}$ & $0.31 \pm 0.03^{a}$ & $47 \pm 9$ & $26 \pm 1$ \\
\hline & 10.0 & $0.64 \pm 0.04^{c}$ & $0.29 \pm 0.01^{b}$ & $64 \pm 2$ & $28 \pm 3$ \\
\hline & 15.0 & $0.40 \pm 0.09^{d}$ & $0.25 \pm 0.02^{c}$ & $37 \pm 2$ & $19 \pm 1$ \\
\hline & 20.0 & $0.21 \pm 0.04^{e}$ & $0.22 \pm 0.02^{d}$ & $31 \pm 4$ & $13 \pm 1$ \\
\hline & 25.0 & $0.13 \pm 0.03^{f}$ & $0.22 \pm 0.02^{d}$ & $26 \pm 2$ & $14 \pm 0$ \\
\hline \multirow[t]{6}{*}{ celeriac, Groma } & 0.0 & $1.11 \pm 0.29^{a}$ & $0.39 \pm 0.02^{a}$ & $36 \pm 2$ & $19 \pm 4$ \\
\hline & 5.0 & $0.75 \pm 0.18^{b}$ & $0.40 \pm 0.04^{a}$ & $30 \pm 2$ & $17 \pm 2$ \\
\hline & 10.0 & $0.32 \pm 0.18^{c}$ & $0.40 \pm 0.06^{a}$ & $27 \pm 4$ & $17 \pm 1$ \\
\hline & 15.0 & $0.08 \pm 0.03^{d}$ & $0.23 \pm 0.05^{b}$ & $25 \pm 4$ & $15 \pm 1$ \\
\hline & 20.0 & $0.04 \pm 0.01^{e}$ & $0.31 \pm 0.05^{c}$ & $17 \pm 2$ & $12 \pm 0$ \\
\hline & 25.0 & $0.03 \pm 0.01^{e}$ & $0.26 \pm 0.04^{b, c}$ & $12 \pm 3$ & $9 \pm 0$ \\
\hline \multirow[t]{6}{*}{ celeriac, Kaufland } & 0.0 & $1.29 \pm 0.18^{a}$ & $0.42 \pm 0.02^{a}$ & $62 \pm 3$ & $26 \pm 4$ \\
\hline & 5.0 & $0.65 \pm 0.26^{b}$ & $0.41 \pm 0.02^{a}$ & $41 \pm 3$ & $26 \pm 1$ \\
\hline & 10.0 & $0.11 \pm 0.03^{c}$ & $0.24 \pm 0.03^{b}$ & $21 \pm 0$ & $23 \pm 2$ \\
\hline & 15.0 & $0.05 \pm 0.01^{d}$ & $0.22 \pm 0.04^{b}$ & $20 \pm 6$ & $10 \pm 0$ \\
\hline & 20.0 & $0.03 \pm 0.01^{d}$ & $0.22 \pm 0.04^{b}$ & $11 \pm 1$ & $8 \pm 1$ \\
\hline & 25.0 & $0.02 \pm 0.01^{e}$ & $0.25 \pm 0.05^{b}$ & $9 \pm 1$ & $6 \pm 0$ \\
\hline
\end{tabular}

IJFS | April 2017 | Volume 6 | pages 1-12 
$8 \mid$ Schmitt et al.

Table 2: Relative fracture height $(\Delta h)$ of waxy and floury potatoes, carrot and celeriac at speeds of 3.6, 4.4 and $5.3 \mathrm{~m} \mathrm{~s}^{-1}$

\begin{tabular}{|c|c|c|c|c|}
\hline food samples & $\mathrm{t}[\mathrm{min}]$ & $\Delta h_{3.6}[\mathrm{~cm}]$ & $\Delta h_{4.4}[\mathrm{~cm}]$ & $\Delta h_{5.3}[\mathrm{~cm}]$ \\
\hline waxy potato, Princess & 0.0 & $21 \pm 1$ & $20 \pm 0$ & $15 \pm 0$ \\
\hline \multirow[t]{6}{*}{ Amandine } & 2.5 & $16 \pm 1$ & $19 \pm 1$ & $15 \pm 3$ \\
\hline & 5.0 & $30 \pm 0$ & $24 \pm 1$ & $29 \pm 1$ \\
\hline & 7.5 & $30 \pm 2$ & $36 \pm 2$ & $28 \pm 1$ \\
\hline & 10.0 & $37 \pm 2$ & $30 \pm 4$ & $25 \pm 0$ \\
\hline & 12.5 & $34 \pm 2$ & $37 \pm 1$ & $23 \pm 3$ \\
\hline & 15.0 & $30 \pm 0$ & $30 \pm 1$ & $26 \pm 2$ \\
\hline \multirow[t]{7}{*}{ floury potato, Alpha } & 0.0 & $19 \pm 1$ & $17 \pm 3$ & $16 \pm 0$ \\
\hline & 2.5 & $24 \pm 2$ & $20 \pm 1$ & $17 \pm 1$ \\
\hline & 5.0 & $31 \pm 2$ & $20 \pm 0$ & $16 \pm 0$ \\
\hline & 7.5 & $34 \pm 1$ & $27 \pm 3$ & $22 \pm 0$ \\
\hline & 10.0 & $34 \pm 2$ & $32 \pm 2$ & $31 \pm 1$ \\
\hline & 12.5 & $48 \pm 4$ & $51 \pm 1$ & $35 \pm 1$ \\
\hline & 15.0 & $42 \pm 0$ & $35 \pm 4$ & $30 \pm 0$ \\
\hline \multirow[t]{7}{*}{ carrot, Frucht Hartmann } & 0.0 & $24 \pm 2$ & $16 \pm 1$ & $19 \pm 1$ \\
\hline & 2.5 & $33 \pm 1$ & $21 \pm 1$ & $20 \pm 2$ \\
\hline & 5.0 & $35 \pm 4$ & $27 \pm 1$ & $20 \pm 0$ \\
\hline & 7.5 & $39 \pm 4$ & $49 \pm 2$ & $28 \pm 3$ \\
\hline & 10.0 & $71 \pm 1$ & $35 \pm 4$ & $22 \pm 1$ \\
\hline & 12.5 & $42 \pm 0$ & $38 \pm 2$ & $28 \pm 1$ \\
\hline & 15.0 & $32 \pm 1$ & $17 \pm 2$ & $15 \pm 1$ \\
\hline \multirow[t]{7}{*}{ celeriac, Frucht Hartmann } & 0.0 & $25 \pm 7$ & $7 \pm 1$ & $22 \pm 0$ \\
\hline & 2.5 & $33 \pm 4$ & $7 \pm 1$ & $20 \pm 0$ \\
\hline & 5.0 & $29 \pm 1$ & $10 \pm 1$ & $20 \pm 0$ \\
\hline & 7.5 & $32 \pm 2$ & $10 \pm 0$ & $21 \pm 1$ \\
\hline & 10.0 & $20 \pm 0$ & $10 \pm 2$ & $18 \pm 0$ \\
\hline & 12.5 & $29 \pm 1$ & $10 \pm 0$ & $18 \pm 3$ \\
\hline & 15.0 & $26 \pm 8$ & $1 \pm 0$ & $12 \pm 1$ \\
\hline
\end{tabular}

cooking. Therefore, relative fracture height decreases at long cooking times.

Table 1 shows no increase of $\sigma$ with increasing cooking time for any of the vegetables. Additionally, an increase of $\varepsilon$ with increasing cooking time could be determined only for carrots and the "Ditta" potato (Table 1). In contrast, the relative fracture energies had maxima for all carrots and potatoes measured (Tables 1 \& 2). Therefore, the pendulum test more clearly exposes the increase of textural values at lower cooking times in comparison with the uniaxial compression test.
According to Table 2, only the "Frucht Hartmann" celeriac showed a minimal increase of $\Delta h_{4.4}$ until 5.0 min. $\Delta h_{4.4}$ was constant from 5.0 to $12.5 \mathrm{~min}$ and decreased with higher cooking times. Relatively constant values of $\Delta h_{3.6}$ and $\Delta h_{5.3}$ were measured until a cooking time of 7.5 and $15.0 \mathrm{~min}$, respectively. There were no general textural maxima detectable for the "Groma" or "Kaufland" celeriacs for all measured parameters, as shown in Table 1. This means that the textural values of celeriacs are different to potatoes and carrots. The differences in the measured textural characteristic between celeriac and pota- 
Texture analysis of blanched vegetables $\mid 9$

toes or carrots are caused by their structure and composition. Celeriac has a sponge-like structure with a high amount of intercellular spaces in comparison with the relatively low amounts of intercellular spaces of potatoes and carrots (Calbo \& Nery, 1995; Slaska-Grzywna, 2010; Hudson, 1975). Hence, it is assumed that cooking water can move directly to the cells at low cooking times (e.g. $5.0 \mathrm{~min}$ ) leading to a faster heat transfer inside the whole celeriac sample. Thus, the degradation process of pectins in the middle lamellae and the cell wall is accelerated by heat induced $\beta$-hydrolytic elimination. This softening process overlays the effect of enzymatic solidification by PME and the strengthening effect of a higher amount of pectins in celeriacs in comparison to potatoes and carrots (Van Marle et al., 1997) (Ternes, 2008). Additionally, the composition of pectins and other substances in the cell walls are specific to the variety of vegetable and influence the measured textural parameters (Kittemann, 2012; Van Marle et al., 1997). However, a determination of this influence could not be specified in this study and can be evaluated in future studies. In summary, the cell walls of celeriacs appear to be destroyed faster than the cell walls of potatoes and carrots. This was also confirmed by a comparison of pictures of the microstructure of celeriac and potatoes, explaining the textural differences between celeriac and the other measured vegetables (Lillford, 2001; Slaska-Grzywna, 2010).

Table 2 indicates a decrease of measured relative fracture height for all vegetables with the increase of the speed of the pendulum from 3.6 to $5.3 \mathrm{~m} \mathrm{~s}^{-1}$. These results are consistent with equation 3 and in accordance with the strain rate dependence of textural values of vegetables (Mohsenin, 1986). No obvious tendency could be recognized in the relative fracture height at $4.4 \mathrm{~m} \mathrm{~s}^{-1}$. The lowest values of relative fracture energies were measured at $\Delta h_{4.4}$ for "Frucht Hartmann" celeriac, independent of the cooking time. There was also a minimum for $\Delta h_{4.4}$ at $\mathrm{t}=0.0 \mathrm{~min}$ and a maximum at $\mathrm{t}=7.5 \mathrm{~min}$ for the "Frucht Hartmann" carrot. The relative fracture height of the "Frucht Hartmann" carrot decreased monotonously with increasing pendulum speed at cooking times of 2.5, 5.0,10.0, 12.5 and $15.0 \mathrm{~min}$. The same tendency could be seen for the "Alpha" potato except at a cooking time of 12.5 min because relative fracture height showed a maximum at a speed of $4.4 \mathrm{~m} \mathrm{~s}^{-1}$. The values of $\Delta h_{4.4}$ for the "Princess Amandine" potato were inconsistent with the general tendency of decreasing relative fracture height with increasing speed. A measurement error could be the reason for these inconsistent values for "Princess Amandine". Therefore, more tests with different speeds should be carried out to evaluate the influence of pendulum speed on relative fracture height.

\section{Conclusions}

One objective of this study was to evaluate if there are differences between high- and low-speed measuring methods for textural values of vegetables while cooking. The transfer of results from low- to high-speed measurement methods is limited due to low- and medium-rank correlation coefficients and different tendencies of the values measured for potatoes, celeriacs and carrots during the cooking process. Hence, high-speed processes of blanched vegetables that are designed based on low-speed measurement values might have to be redesigned or optimized based on values measured with high-speed methods.

The second objective was an analysis of a possible increase of textural values of blanched vegetables with high-speed measuring methods. The increase of relative fracture height with cooking time evaluated with the high-speed pendulum test was even more pronounced for potatoes and carrots in comparison with the results of the lowspeed uniaxial compression test. The increase of textural values due to blanching depends on the variety of vegetable; e. g. there was a lack of textural increase for celeriac samples. Hence, a textural analysis at process speed with the respective vegetables is necessary to reduce the risk of quality loss due to fracture.

\section{Acknowledgements}

The authors would like to thank Corinna Diegelmann, Sarah Goldbach and Mara Lindner for their assistance in the preliminary studies. 


\section{References}

Agulheiro Santos, A. \& Roseiro, C. (2012). Physical properties of foods: novel measurement techniques and applications. In I. Arana (Ed.), (Chap. Rheological Properties of Foods, pp. 23-88). CRC Press.

Alvarez, M. D., Canet, W., \& Tortosa, M. E. (2001). Kinetics of thermal softening of potato tissue (cv. monalisa) by water heating. European Food Research and Technology, 212(5), 588-596. doi:10 . 1007/ s002170100295

Benen, J. A. E., Van Alebeek, G. J. W. M., \& Voragen, A. G. J. (2003). Handbook of food enzymology. New York: CRC Press Taylor \& Francis Group. Retrieved from http : / / 197. 14 . 51 . 10 : 81 / pmb / AGROALIMENTAIRE / Food Enzymology.pdf

Bentini, M., Caprara, C., \& Martelli, R. (2006). Harvesting damage to potato tubers by analysis of impacts recorded with an instrumented sphere. Biosystems Engineering, 94 (1), 75-85.

Bourne, M. C. (2002a). Chapter 1 - texture, viscosity, and food. In M. C. Bourne (Ed.), Food texture and viscosity (second edition) (Second Edition, pp. 1-32). Food Science and Technology. London: Academic Press. doi:10.1016/B978-012119062-0/50001-2

Bourne, M. C. (2002b). Chapter 3 - physics and texture. In M. C. Bourne (Ed.), Food texture and viscosity (second edition) (Second Edition, pp. 59-106). Food Science and Technology. London: Academic Press. doi:10.1016/B978-012119062-0/50003-6

Bourne, M. C. (2002c). Chapter 4 - principles of objective texture measurement. In M. C. Bourne (Ed.), Food texture and viscosity (second edition) (Second Edition, pp. 107188). Food Science and Technology. London: Academic Press. doi:10.1016/B978012119062-0/50004-8

Brejnholt, S. M. (2009). Pectin. In Food stabilisers, thickeners and gelling agents (pp. 237-265). Wiley-Blackwell. doi:10 . 1002/9781444314724.ch13
Bühl, A. (2010). Spss 18 (ehemals pasw): einführung in die moderne datenanalyse. Tata McGraw-Hill Education.

Calbo, A. G. \& Nery, A. A. (1995). Methods for measurement of gas volume of fruits and vegetables. Journal of the American Society for Horticultural Science, 120(2), 217221.

Dave, B. A. \& Vaughn, R. H. (1971). Purification and properties of a polygalacturonic acid trans-eliminase produced by bacilluspumilus. Journal of Bacteriology, 108(1), 166-\&.

Dutt, B. K. \& Datta, A. C. (1999). Dynamic and quasi-static force and energy requirement for detachment and breakage of chickpea pedicel and pod. Transactions of the ASAE, 42(2), 309-318.

Fachin, D., Van Loey, A., Indrawati, Ludikhuyze, L., \& Hendrickx, M. (2002). Thermal and high-pressure inactivation of tomato polygalacturonase: a kinetic study. Journal of Food Science, 67(5), 1610-1615. doi:10 . 1111/j.1365-2621.2002.tb08692.x

Hamann, D. D., Zhang, J., Daubert, C. R., Foegeding, E. A., \& Diehl, K. C., Jr. (2006). Analysis of compression, tension and torsion for testing food gel fracture properties. Journal of Texture Studies, 37(6), 620-639. doi:10.1111/j.17454603.2006.00074.x

Hudson, D. E. (1975). The relationship of cell size, intercellular space, and specific gravity to bruise depth in potatoes. American Potato Journal, 52(1), 9-14. doi:10.1007/ BF02852100

Jarvis, M. C. (1998). Intercellular separation forces generated by intracellular pressure. Plant Cell and Environment, 21 (12), 13071310. doi:10.1046/j.1365-3040.1998.00363. $\mathrm{x}$

Khan, A. A. \& Vincent, J. F. V. (1993). Compressive stiffness and fracture properties of apple and potato parenchyma. Journal of Texture Studies, 24(4), 423-435. doi:10 . 1111/j.1745-4603.1993.tb00052.x

Kittemann, D. (2012). Untersuchungen zu fruchtfleischfestigkeit und zellwandabbau von apfelfrüchten während der lagerung unter besonderer berücksichtigung des ein- 
flusses von ethylen (Doctoral dissertation, München, Technische Universität München, Diss., 2012).

Kresic, G., Lelas, V., \& Simundic, B. (2004). Effects of processing on nutritional composition and quality evaluation of candied celeriac. Sadhana - Academy Proceedings in Engineering Sciences, 29(1), 1-12. doi:10. 1007 /BF02706997

Lillford, P. J. (2001). Mechanisms of fracture in foods. Journal of Texture Studies, 32(5-6), 397-417. doi:10.1111/j.1745-4603. 2001. tb01244.x

Liu, X. Y., Macmillan, R. H., Burrow, R. P., Kadkol, G. P., \& Halloran, G. M. (1994). Pendulum test for evaluation of the rupture strength of seed pods. Journal of Texture Studies, 25(2), 179-189. doi:10.1111/ j.1745-4603.1994.tb01325.x

Lu, R. \& Abbott, J. A. (2004). 5 force/deformation techniques for measuring texture. In D. Kilcast (Ed.), Texture in food (pp. 109-145). Woodhead Publishing Series in Food Science, Technology and Nutrition. Woodhead Publishing. doi:10.1533/978185538362.2.109

Luyten, H., Vanvliet, T., \& Walstra, P. (1992). Comparison of various methods to evaluate fracture phenomena in food materials. Journal of Texture Studies, 23(3), 245-266. doi:10.1111/j.1745-4603.1992.tb00524.x

Mohsenin, N. N. (1986). Physical properties of plant and animal materials. Gordon and Breach.

Peleg, M. (2006). On fundamental issues in texture evaluation and texturization - a view. Food Hydrocolloids, 20(4), 405-414. Part Special issue: $\{$ WCFS $\}$ Food Summit. doi:http://dx.doi.org/10.1016/j.foodhyd. 2005.10.008

Rehman, H. U., Aman, A., Nawaz, M. A., Karim, A., Ghani, M., Baloch, A. H., \& Ul Qader, S. A. (2016). Immobilization of pectin depolymerising polygalacturonase using different polymers. International Journal of Biological Macromolecules, 82, 127-133. doi:10.1016/j.ijbiomac.2015.10.012

Sajnin, C., Gerschenson, L. N., \& Rojas, A. M. (1999). Turgor pressure in vegetable tissues: comparison of the performance of in- cipient plasmolysis technique using mannitol and polyethylenglycol. Food Research International, 32(8), 531-537. doi:10.1016/ S0963-9969(99)00121-0

Sila, D. N., Smout, C., Vu, S. T., Van Loey, A., \& Hendrickx, M. (2005). Influence of pretreatment conditions on the texture and cell wall components of carrots during thermal processing. Journal of Food Science, 70(2), E85-E91. doi:10.1111/j.1365-2621. 2005.tb07095.x

Slaska-Grzywna, B. (2010). Changes in mechanical properties and microstructure of root of celery after thermal treatment. Teka Komisji Motoryzacji i Energetyki Rolnictwa, 10.

Ternes, W. (2008). Naturwissenschaftliche grundlagen der lebensmittelzubereitung. Behr. Retrieved from https : / / books . google.de/books?id=eHEvqVXoVJsC

Van Buren, J. P. (1973). Improves firmness without additives. Food Engineering, 45(5), 127-127.

Van Dijk, C., Beekhuizen, J.-G., Gibcens, T., Boeriu, C., Fischer, M., \& Stolle-Smits, T. (2002). Texture of cooked potatoes (solanum tuberosum). 2. changes in pectin composition during storage of potatoes. Journal of Agricultural and Food Chemistry, 50(18), 5089-5097. PMID: 12188613. doi:10.1021/jf011510v

Van Dijk, C., Fischer, M., Beekhuizen, J.-G., Boeriu, C., \& Stolle-Smits, T. (2002). Texture of cooked potatoes (solanum tuberosum). 3. preheating and the consequences for the texture and cell wall chemistry. Journal of Agricultural and Food Chemistry, 50(18), 5098-5106. PMID: 12188614. doi:10.1021/jf011511n

Van Marle, J. T., Stolle Smits, T., Donkers, J., Van Dijk, C., Voragen, A. G. J., \& Recourt, K. (1997). Chemical and microscopic characterization of potato (solanum tuberosum l) cell walls during cooking. Journal of Agricultural and Food Chemistry, 45(1), 50-58. doi:10.1021/jf960085g

Waldron, K. W. (2004). 10 - plant structure and fruit and vegetable texture. In D. Kilcast (Ed.), Texture in food (pp. 241-258). Woodhead Publishing Series in Food Sci- 
$12 \mid$ Schmitt et al.

ence, Technology and Nutrition. Woodhead

Publishing. doi:10.1533/978185538362.3.

243

IJFS | April 2017 | Volume 6 | pages 1-12 